\title{
Operational Control of Eurasian Watermilfoil (Myriophyllum spicatum) and Impacts to the Native Submersed Aquatic Macrophyte Community in Lake Pend Oreille, Idaho
}

\author{
John D. Madsen, Ryan M. Wersal, and Thomas E. Woolf*
}

\begin{abstract}
Lake Pend Oreille is the largest (36,000 ha or 91,000 ac) freshwater lake in Idaho. Approximately $27 \%$ or 10,000 ha of the lake is littoral zone habitat supporting aquatic macrophyte growth. Eurasian watermilfoil has invaded large areas of this littoral zone habitat, with early estimates suggesting approximately 2,000 ha by the mid 2000s. Idaho State Department of Agriculture developed a state-wide eradication program in response to the threats posed by Eurasian watermilfoil, which attempts to quantify Eurasian watermilfoil infestations and its effects on the native plant community. Littoral zone point intercept surveys were conducted in 2007 and 2008 to monitor the trends in aquatic macrophyte community structure and assess management strategies against Eurasian watermilfoil. Lake Pend Oreille has a species-rich aquatic macrophyte community of more than 50 species. Lake-wide, the presence of Eurasian watermilfoil significantly decreased from $2007(12.5 \%)$ to $2008(7.9 \%)$. The native plant community has remained stable from 2007 to 2008 despite lake-wide management activities. In managed areas, the frequency of Eurasian watermilfoil during the 2008 assessment was $23.6 \%$ after herbicide applications. This represents a $63 \%$ reduction in Eurasian watermilfoil presence from the 2007 (64.5\%) survey. When 2,4-D was combined with endothall, the presence of Eurasian watermilfoil declined from $63 \%$ (2007) to $36.5 \%$ in 2008. Eurasian watermilfoil treated with triclopyr also declined significantly, $64 \%$ to $18.2 \%$. When all treatment methods were pooled and compared with areas that were not treated, the presence of Eurasian watermilfoil was significantly greater $(52.5 \%)$ in untreated areas as opposed to treated areas (23\%). The removal of Eurasian watermilfoil resulted in an increase in native species in most areas. Currently, there is as little as 200 ha of Eurasian watermilfoil remaining, which represents an overall reduction of $90 \%$ in approximately $7 \mathrm{yr}$ of management. Nomenclature: Fluridone; triclopyr; 2,4-D; endothall; Eurasian watermilfoil, Myriophyllum spicatum L. MYSP2. Key words: Aquatic macrophyte management, herbicide selectivity, invasive species, lake management, native macrophyte.
\end{abstract}

Aquatic macrophytes are important to lake ecosystems (Madsen et al. 1996; Wetzel 2001) and are essential in promoting the diversity and function of an aquatic system (Carpenter and Lodge 1986). Littoral zone habitat and associated plants may be responsible for a significant proportion of primary production for the entire lake (Ozimek et al. 1990; Wetzel 2001). Littoral zone habitats

\section{DOI: $10.1614 /$ IPSM-D-14-00008.1}

* First author: Research Biologist, USDA Agricultural Research Service Exotic and Invasive Weeds Research Unit, University of California-Davis, Department of Plant Sciences, Davis, CA 95616; second author: Aquatic Plant Scientist, Lonza, 1200 Bluegrass Lakes Parkway, Alpharetta, GA 30004; third author: Aquatic Plant Program Manager, Idaho State Department of Agriculture, Box 790, Boise, ID 83701. Corresponding author's E-mail: jmadsen@ucdavis.edu are prime areas for the spawning of most fish species, including many species important to sport fisheries (Savino and Stein 1989). Furthermore, aquatic macrophytes anchor soft sediments, stabilize underwater slopes, remove suspended particles, and remove nutrients from overlying waters (Barko et al. 1986; Doyle 2000; Madsen et al. 2001). However, when nonnative plants invade littoral zone habitat, changes in biotic and abiotic interactions often occurs (Madsen 1998). The growth of nonnative species often results in reductions in littoral zone plant species that may affect fish reproduction (Savino and Stein 1989), sediment resuspension, turbidity, and algal production; the latter will further exacerbate plant loss (Doyle 2000; Case and Madsen 2004; Madsen et al. 1996; Wersal et al. 2006).

Eurasian watermilfoil (Myriophyllum spicatum L.) is an invasive vascular plant that has invaded freshwater lakes 


\section{Management Implications}

Lake Pend Oreille is a large fluctuating reservoir with a speciesrich aquatic macrophyte community that shifts from early- to lateseason species. The management of Eurasian watermilfoil has promoted growth of native plants. Eurasian watermilfoil was reduced by $63 \%$ at sites treated before September 2008. Results suggest that fluridone applications should be limited to areas of low water exchange to enhance efficacy. The combination of 2,4$\mathrm{D}$ and endothall applied in areas of higher water exchange rates resulted in significant reductions of Eurasian watermilfoil, although the addition of a contact herbicide may have resulted in a temporary loss of some native species. Triclopyr use also resulted in a reduction of Eurasian watermilfoil frequency in treatment plots, with less effect on native plants. The combination of triclopyr and endothall in areas of high water exchange was effective in a preliminary assessment, although additional studies are needed. On the basis of our analyses, the presence of Eurasian watermilfoil was more detrimental to the native plant community than the herbicide treatments.

across the United States. The introduction of Eurasian watermilfoil to a waterbody often results in the alteration of the complex interactions occurring in aquatic ecosystems (Engelhardt and Ritchie 2002; Madsen 1998). Dense beds of Eurasian watermilfoil are often responsible for reductions in oxygen exchange, depletion of dissolved oxygen, increases in water temperature, and internal nutrient loading (Madsen 1998). Monotypic stands of Eurasian watermilfoil reduce native plant species richness and diversity (Madsen et al. $1991 b, 2008)$ and also affect habitat complexity, resulting in reductions in macroinvertebrate abundance (Keast 1984; Krull 1970) and reductions in fish growth (Lillie and Budd 1992). In areas where Eurasian watermilfoil has invaded, water resource managers are concerned about the effects that this plant has on human uses, such as interfering with hydropower generation, flood control, and recreation. In Idaho, Eurasian watermilfoil has invaded and established populations in Lake Pend Oreille, the state's largest $(36,400$ ha, 91,000 ac) freshwater lake.

Lake Pend Oreille has approximately 8,400 ha of littoral zone habitat for aquatic macrophyte growth, meaning Eurasian watermilfoil could inhabit roughly $27 \%$ of the total lake area. Early estimates (2004-2005) suggested that there may have been as much as 2,000 ha of Eurasian watermilfoil before the development of a management program. The establishment of Eurasian watermilfoil and subsequent spread is likely perpetuated by the ease of fragmentation (both physical and physiological) of this plant, the large fetch of the lake, and the high watercraft traffic that moves fragments to new areas. Repeated disturbance, such as current, wave action, and human uses, results in temporal changes in the plant composition and may create new habitat for nonnative plant colonization. Moreover, freshwater systems are often vulnerable to invasion because of repeated disturbance (Shea and Chesson
2002). Once this species has invaded and established, it can be difficult to control, depending on the local conditions. Pursuant to the difficulty of control and the economic and ecological threats posed by Eurasian watermilfoil, the Idaho State Department of Agriculture has developed and implemented a statewide Eurasian watermilfoil management program. An important component of this program is the development of an adequate monitoring and assessment system to evaluate the effect of control techniques on both the target and nontarget plant species.

Although Pend Oreille Lake is a natural lake, the Albeni Falls Dam on the downstream end of the lake does control water levels and is used for hydropower production. The predominant use of the dam, however, is for flood control and water storage, rather than hydropower generation. For the past decade, the hydrology of the lake has been managed using a $3.3-\mathrm{m}(11-\mathrm{ft})$ drawdown during the early fall and winter to capture the spring flood pulse. Snowmelt in the spring brings heavy flows of cold water. Because much of the snowmelt may continue into May and June, and Pend Oreille Lake is extremely deep, and the water temperatures do not rise above 15 C (59 F) until late June or July. Plants may not begin actively growing in the lake until July. With the combined possibility of heavy snowmelt and rain, the flow patterns into the lake are more stable in the late summer and early fall. Because of this, the best times to treat Eurasian watermilfoil are from mid-July until mid-October. Aquatic macrophyte management must take place between highwater flows and low-water temperatures in the spring, and cool-water temperatures in the fall.

Pend Oreille Lake is not only a difficult water environment in which to work, but it has significant regulatory and public constraints on management. A vocal minority of residents vigorously opposed herbicide treatments, resulting in long and acrimonious public meetings. In the initial years, nonchemical alternatives to herbicides were attempted, including hand pulling, bottom barrier and diver-operated suction dredging. These techniques clearly could not achieve acceptable control within economic limits imposed by the program. Herbicide selection was often dictated by considerations other than cost, efficacy, or water exposure time constraints. Several municipal drinking water intakes are located on the lake, some near herbicide treatment areas. While much of the lake bottom is owned by the state, the shallows in some areas are owned and managed by the U.S. Army Corps of Engineers, which necessitated an Endangered Species Act consultation to identify herbicides with an acceptable level of risk to endangered species, particularly the bull trout (Salvelinus confluentus (Suckley, 1859)), as determined by the regional U.S. Fish and Wildlife Service. The Idaho State Department of Fish and Game also has species of concern, in particular the introduced kokanee salmon, a landlocked population of sockeye salmon (Oncorhynchus 
nerka (Walbaum in Artedi, 1792)) that were introduced to the lake by Idaho State Department of Fish and Game, which is viewed as a food source for Bull Trout. Lastly, the Talent River Decision by the Federal 9th District Court required residue sampling and compliance issues that foreshadowed the federally mandated National Pollutant Discharge Elimination System compliance for aquatic herbicide applications.

Water clarity (as measured by Secchi disk depth) in Pend Oreille Lake ranges from 2 to $7 \mathrm{~m}$, depending on location and season (Madsen and Wersal 2008, 2009). Vascular aquatic macrophytes were found to a depth of $10 \mathrm{~m}$, and macroalgae Chara L. and Nitella C. A. Agardh to a depth of more than $13 \mathrm{~m}$. The high water clarity of this lake allows aquatic macrophyte growth to extreme depths. The lake is classified as oligotrophic, with some bays ranging from mesotrophic to eutrophic. The riverine portion is classed as oligo-mesotrophic (USEPA 1993). According to the USEPA (1993), the water quality of the open-water areas of the lake have not changed statistically since the 1950s.

The point intercept method is an effective and efficient method to survey large areas and collect large quantities of data on plant distribution (Madsen 1999). The point intercept survey is a simple method that allows for rapid data collection during large multiyear studies, but most importantly, it offers the ability to conduct a quantitative statistical assessment of control techniques. The use of point intercept surveys allows for a quantitative assessment of the temporal changes in aquatic macrophyte species composition lake-wide (Wersal et al. 2010). This survey method is also sensitive to interannual changes in macrophyte occurrences (Madsen 1999), which will offer further insights into how the native macrophyte community is responding to management of Eurasian watermilfoil. Therefore, the objectives of this study were (1) to document the spatial and temporal distribution of the littoral zone aquatic macrophyte community in Lake Pend Oreille, (2) to conduct pre- and posttreatment surveys to assess the effectiveness of management techniques for control of Eurasian watermilfoil, and (3) to determine the effects of management on native submersed macrophytes. The study provided information and insights regarding native species richness, changes in native species assemblages in response to the presence and or removal of Eurasian watermilfoil lakewide, and the presence of new Eurasian watermilfoil infestations throughout Lake Pend Oreille. Intensive surveying has been cited as the only effective way to determine a program's success (Simberloff 2003).

\section{Materials and Methods}

Littoral Zone Surveys. The littoral zone aquatic macrophyte community in Lake Pend Oreille was surveyed in late July to August 2007 and 2008 using point intercept surveys

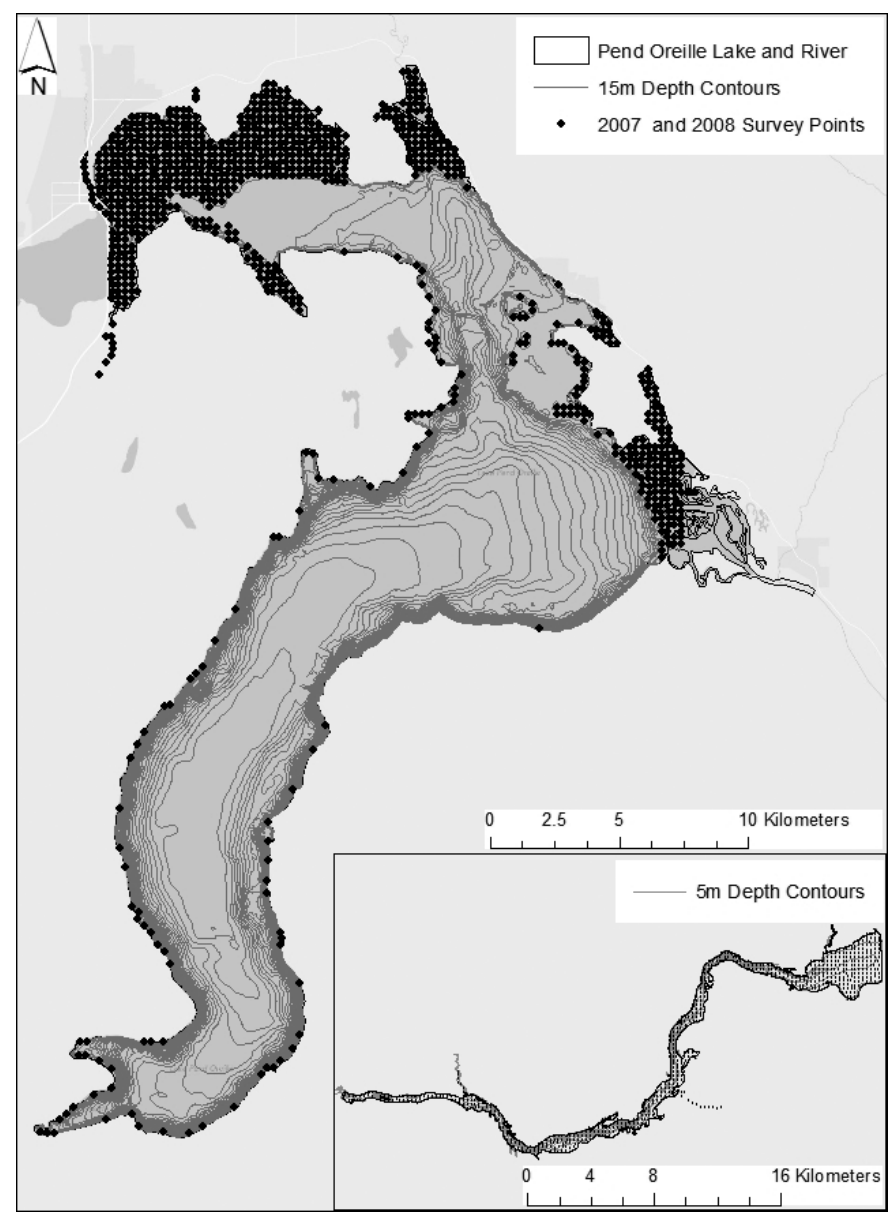

Figure 1. Littoral survey points sampled in 2007 and 2008 in Lake Pend Oreille to assess the aquatic macrophyte community. Sample points in the main portion of the lake were established based on the 0-15-m depth contour. Because of the small area, the entire river was surveyed.

on a 250-m grid following methods outlined by Madsen (1999). The littoral zone was defined as those areas in $15 \mathrm{~m}$ of water or less as determined by light availability to bottom sediments. A total of 1,679 points were sampled in 2007 and the same points sampled in 2008 to allow for the analysis of temporal changes (Figure 1). A GPS receiver (Trimble AgGPS106, Sunnyvale, CA 94085) coupled with a ruggedized laptop computer (Panasonic C-29 Toughbook, Secaucus, NJ 07094) computer was used to achieve 1- to 3-m survey accuracy. At each survey point, a weighted plant rake was deployed to determine the presence of macrophyte species. Additionally, the depth at each point was recorded. Spatial data were recorded electronically using Farm Works Site Mate software (Trimble) that also allowed for navigation to specific survey points as well as displaying and collecting geographic and attribute data while in the field, thus eliminating data entry errors and postprocessing time. Collected data were recorded in database templates using specific pick lists constructed for this project. 
Table 1. Management treatments used in Pend Oreille Lake, ID, in 2007 and 2008 for each approach.

\begin{tabular}{lcc}
\hline & \multicolumn{2}{c}{ Hectares (acres) treated } \\
\cline { 2 - 3 } Management approach & 2007 & 2008 \\
\hline $\begin{array}{l}\text { Diver-operated suction dredge } \\
\text { Herbicides }\end{array}$ & $24(60)$ & \\
$\quad$ 2,4-D, granular & & $107(268)$ \\
$\quad \begin{array}{l}\text { Diquat, liquid } \\
\text { Fluridone, granular }\end{array}$ & $316(790)$ & $1.6(4)$ \\
$\quad \begin{array}{l}\text { Triclopyr, liquid } \\
\text { Triclopyr, granular }\end{array}$ & $524(1,311)$ & $524(1,310)$ \\
$\begin{array}{l}\text { 2,4-D and endothall } \\
\quad \text { combination, liquid }\end{array}$ & & $120(299)$ \\
$\quad \begin{array}{l}\text { Triclopyr and endothall } \\
\quad \text { combination, liquid }\end{array}$ & & $13(32)$ \\
Total & $864(2,161)$ & $766(1,914)$ \\
\hline
\end{tabular}

Herbicide Assessment Surveys. Assessment surveys utilized point intercept techniques similar to those described for the littoral zone surveys; however, assessment surveys utilized a 100-m grid. In 2007 and 2008, a pretreatment survey consisting of 1,758 points was conducted in June to determine locations of Eurasian watermilfoil before the use of management techniques. A posttreatment survey in August and early September of both 2007 and 2008 were conducted in those areas surveyed at least $4 \mathrm{wk}$ after treatment. Eurasian watermilfoil locations discovered during the littoral surveys were examined more closely during the posttreatment survey, in addition to the herbicide treatment areas. All areas were included in the posttreatment survey regardless of whether herbicide applications were made. These untreated areas serve as reference sites for comparison to treated areas. During each survey, the presence or absence of plant species were recorded at each point by deploying a plant rake. Additionally, water depth was recorded at each point. In 2008, areas that were treated in 2007 were used to make between-year comparisons. A total of 1,130 points were sampled during the 2008 assessment survey to assess the efficacy of management activities. Pretreatment and posttreatment surveys were conducted at times similar to those used in 2007.

Operational Management. In 2007, after the pretreatment survey, the granular formulation of triclopyr (Renovate OTF, SePRO Corporation, Carmel, IN 46032) applied at 24.7 to $42.6 \mathrm{~kg}$ ae ha ${ }^{-1}$ (22 to $38 \mathrm{lb}$ $\mathrm{ac}^{-1}$ ), granular fluridone (Sonar, SePRO Corporation) applied at 2.2 to $7.8 \mathrm{~kg}$ ai ha ${ }^{-1}\left(2\right.$ to $7 \mathrm{lb} \mathrm{ac}^{-1}$ ) and diveroperated suction dredging (hereafter referred to as diver dredging) were used to control Eurasian watermilfoil. A total of 864 ha were managed for Eurasian watermilfoil in

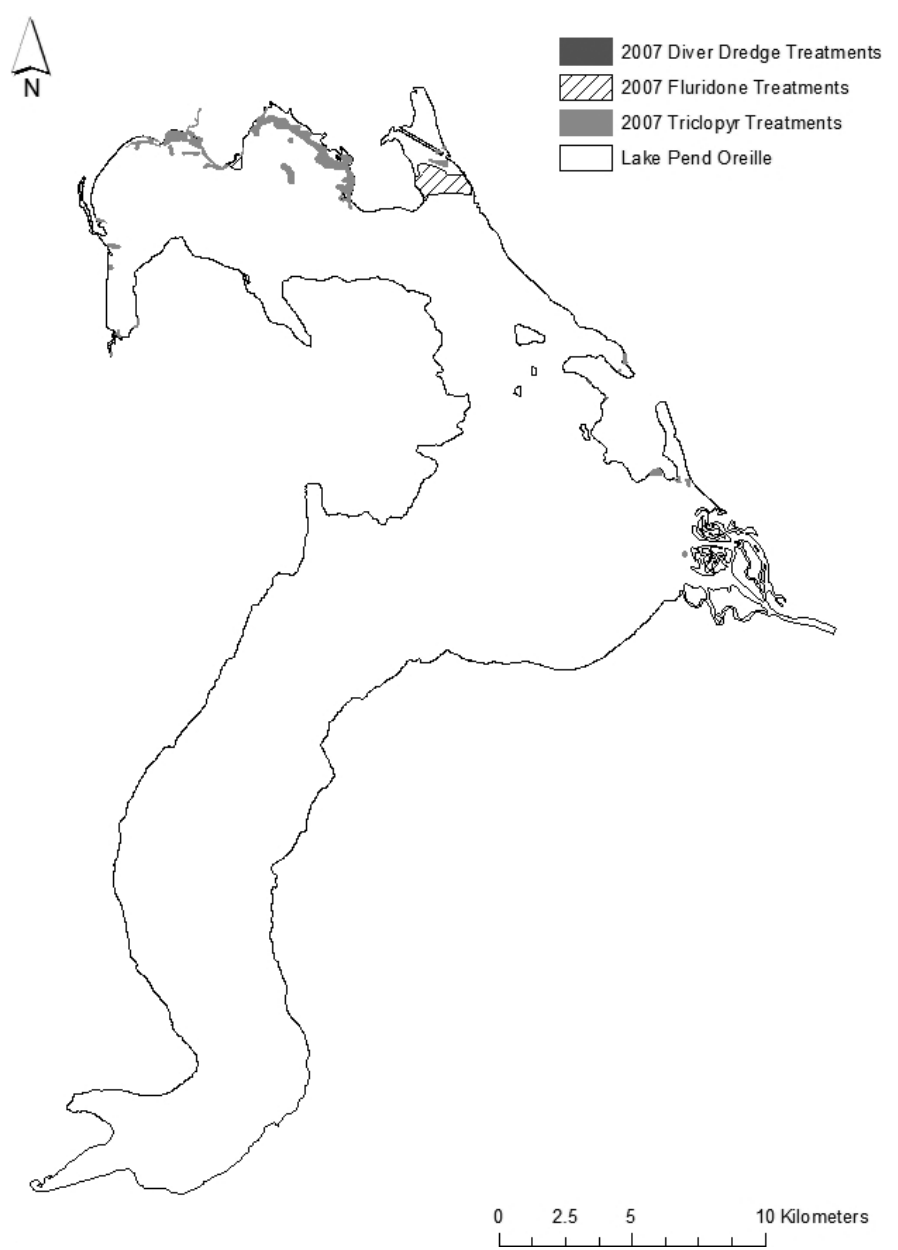

Figure 2. Treatment areas in the main portion of Lake Pend Oreille during the 2007 application season. Triclopyr was treated on 344 ha in 23 sites; fluridone was treated on 196 ha in 2 sites.

2007 (Table 1; Figures 2 and 3). Individual treatment plots ranged from 0.4 to 42 ha. Treatments were conducted between early July to late August 2007.

In 2008, 2,4-D applied as a granular (Navigate, Applied Biochemists, Germantown, WI 53022) or liquid (Weedar 64, Nufarm Agricultural Products, Burr Ridge, IL 60527), triclopyr applied as Ecotriclopyr (Alligare LLC, Opelika, AL 36801), or combinations of 2,4-D (Weedar 64) or triclopyr with endothall (applied as Aquathol K, United Phosphorus Inc., King of Prussia, PA 19406). Diquat was also applied as Reward (Syngenta Professional Products, Greensboro, NC 24719) in 2008; however, only 1.6 ha were treated, so diquat-treated plots were not included in analyses. Granular 2,4-D was always applied alone to achieve a concentration of 0.75 to $1.5 \mathrm{mg} \mathrm{ae} \mathrm{L}^{-1}$ (parts per million, 2 to $4 \mathrm{lb}$ ae ac- $\mathrm{ft}^{-1}$. When triclopyr was applied alone, the target concentration was 0.75 to $1.50 \mathrm{mg}$ ae $\mathrm{L}^{-1}$ (2 to $4 \mathrm{lb}$ ae ac- $\left.\mathrm{ft}^{-1}\right)$. The combination treatments were applied with 2,4-D (0.5 to $1.25 \mathrm{mg}$ ae $\mathrm{L}^{-1}, 1.35$ to $3.38 \mathrm{lb}$ ae ac- $\mathrm{ft}^{-1}$ and endothall (0.7 to $1.3 \mathrm{mg}$ ae $\mathrm{L}^{-1}, 1.8$ to $3.6 \mathrm{lb}$ ae ac- $-\mathrm{ft}^{-1}$ ) or triclopyr 

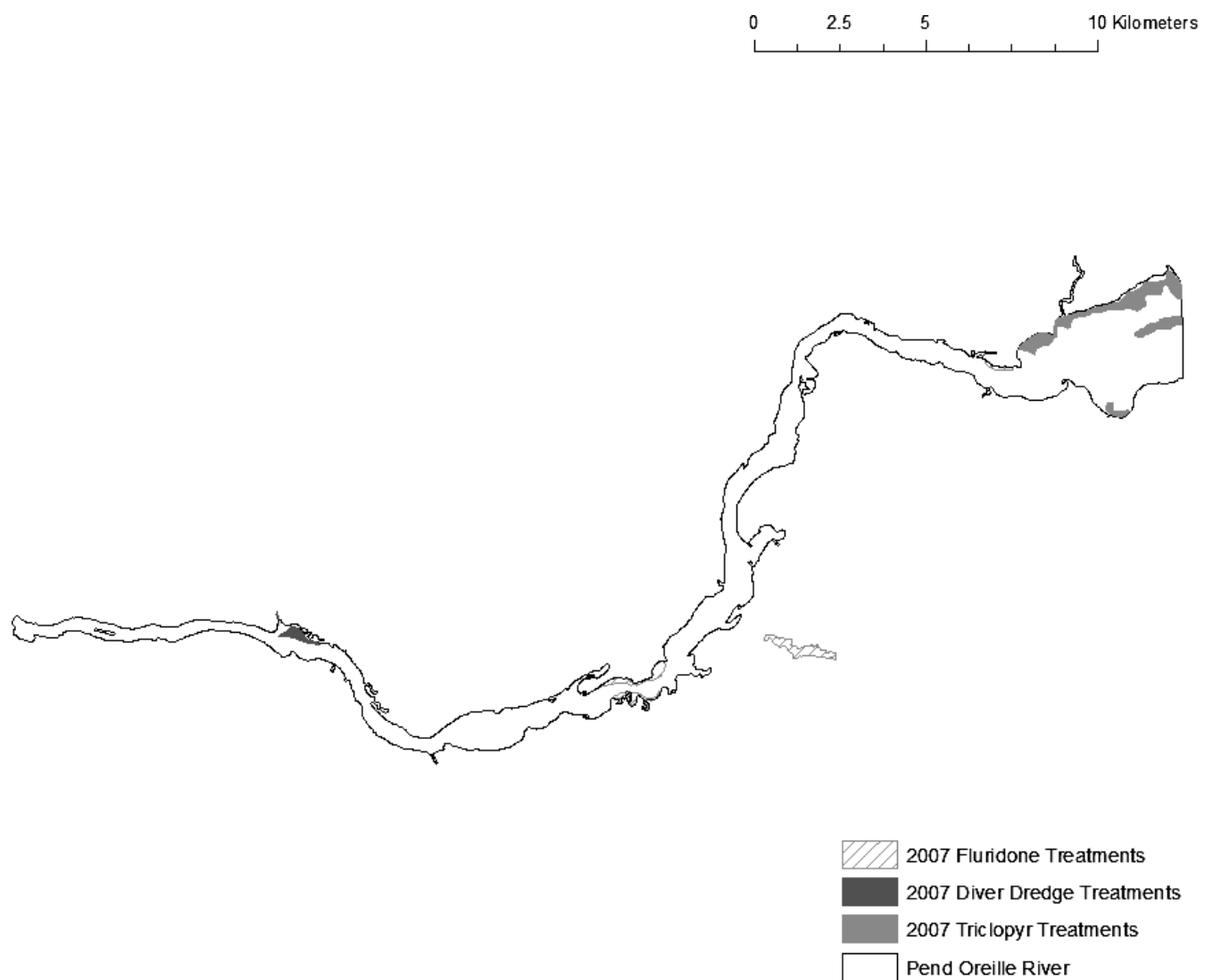

Figure 3. Treatment areas in the river portion of Lake Pend Oreille during the 2007 application season. Triclopyr was applied to 199 ha in four sites, fluridone was treated in 104 ha at four sites.

(0.5 to $1.1 \mathrm{mg}$ ae $\mathrm{L}^{-1}, 1.35$ to $3 \mathrm{lb} \mathrm{ac}-\mathrm{ft}^{-1}$ ) and endothall (0.5 to $2.0 \mathrm{mg}$ ae $\mathrm{L}^{-1}, 1.35$ to $5.4 \mathrm{lb}$ ae ac- $\mathrm{ft}^{-1}$ ). A total of 766 ha were treated in 2008 (Table 1; Figures 4 and 5). As in 2007, individual treatment plots ranged from 0.4 to 42 ha. Treatments were conducted between late June through early October of 2008.

Data Analysis. Plant species presence was averaged over all points sampled and multiplied by 100 to report the frequency of occurrence for each species. Total species richness was calculated and presented as the mean $( \pm 1 \mathrm{SE})$ of all species observed at each point. Native and nonnative species richness was calculated in a similar fashion. Comparisons between the 2007 and 2008 seasons were made using the late-season survey from 2007 in an attempt to alleviate the effects of seasonal variability in plant growth between years. It is important to note that the 2008 assessment survey was conducted in early September; however, approximately $50 \%$ of herbicide treatments were made after this survey in late September and into October. These late treatment areas were not included in the analyses done to assess a particular herbicide's efficacy between years. Data collected during the 2007 assessment survey were clipped using ArcMap software (ESRI, Inc., Redlands, CA) to the treatment boundaries of
2008 to ensure that all analyses and inferences were made for identical areas and points between years.

Survey data were pooled according to year and herbicide for comparison. Changes in the occurrence of plant species across all herbicides and within a given herbicide was determined using McNemar's test to assess differences in the correlated proportions within a given data set between variables that are not independent (Stokes et al. 2000; Wersal et al. 2006). A pairwise comparison of each species was made between years using the Cochran-MantelHaenszel statistic (Stokes et al. 2000; Wersal et al. 2006). Additional sites were treated after assessments were made in 2008. A chi-square test was used to assess the overall effectiveness of herbicide treatment (sites treated before September 2008) compared with no treatment (sites treated after the survey in 2008). Total species richness and native species richness for 2007 and 2008 were also compared using a Wilcoxon rank sum test. All statistical analyses were conducted at the $\mathrm{P} \leq 0.05$ significance level.

\section{Results and Discussion}

Littoral Surveys. The Lake Pend Oreille system has a diverse assemblage of aquatic macrophytes with approximately 51 


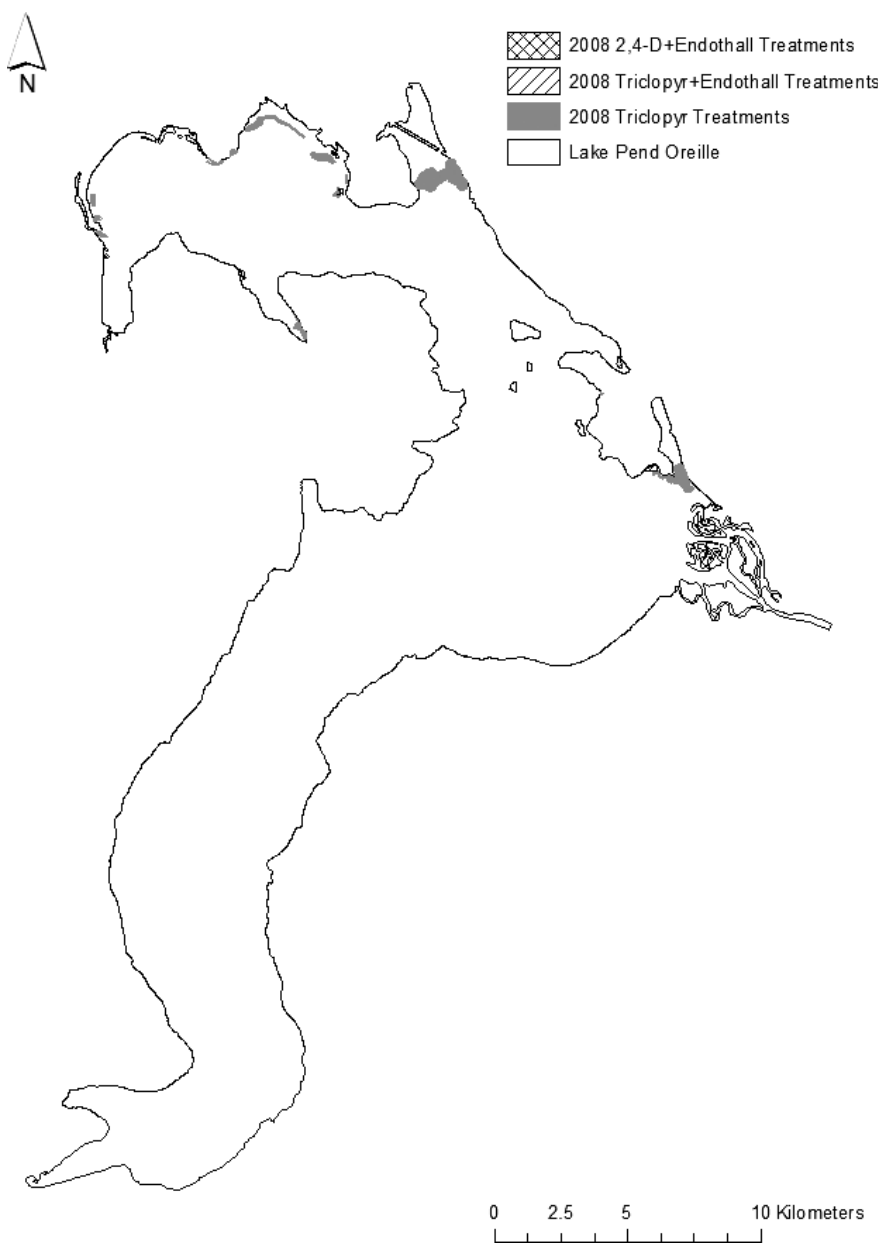

Figure 4. Treatment areas in the main portion of Lake Pend Oreille during the 2008 application season. 2,4-D was treated on 4 ha in 1 plot, triclopyr on 318 ha in 26 plots, a 2,4-D/endothall combination on 83 ha in 10 plots, and a triclopyr/endothall combination on 13 ha in 5 plots.

different species observed during surveys conducted in 2007 (Table 2). Lake Pend Oreille can be divided into a lake portion and a more riverine portion. Overall, fewer species were detected in the riverine portion than in the lake portion. In 2008, the littoral survey yielded 42 plant species. Chara (Chara sp.) was the most common taxon observed in 2007 (29.4\%) and 2008 (22.0\%). Herbicides such as fluridone, endothall, and triclopyr have little to no effect on the growth of chara (Crowell et al. 2006; Hofstra and Clayton 2001; Parsons et al. 2004). Dominant native vascular plant species, excluding chara, were leafy pondweed (Potamogeton foliosus Raf.) that had a frequency of occurrence of $13.7 \%$ and $14.3 \%$ in 2007 and 2008, respectively, followed by elodea (Elodea canadensis Michx.), and sago pondweed [Stuckenia pectinata (L.) Börner]. Native northern watermilfoil increased from $2.0 \%$ in 2007 to $4.2 \%$ in 2008. The presence of Eurasian watermilfoil declined from $12.5 \%$ in 2007 to $7.9 \%$ in
2008 , a $37 \%$ decline in the presence of this species lakewide. At the time of the littoral survey the majority of Eurasian watermilfoil observations were in the river (i.e., west of the town of Sandpoint) and in the northern portion of the lake where Pack River enters. In 2007, large areas west of Sandpoint were not managed for Eurasian watermilfoil, which would explain the increased observations in this area during the 2008 littoral survey.

Depth Distribution. In general, native species occurred from water depths of $0.6 \mathrm{~m}$ to as deep as $7.5 \mathrm{~m}$, with the majority of species growing in water depths between 1.5 and $4.5 \mathrm{~m}$ of water. Native species had $\geq 80 \%$ occurrence at water depths of $1.5 \mathrm{~m}$. Chara was the native species found most often in water depths greater than $7.5 \mathrm{~m}$; however, pondweeds, coontail (Ceratophyllum demersum L.), and elodea were also found at these greater depths. Eurasian watermilfoil was present at approximately 20 to $40 \%$ of all points at water depths between 3 and $4.5 \mathrm{~m}$ and was observed growing to a depth of $9 \mathrm{~m}$. With a depth distribution of $9 \mathrm{~m}$, Eurasian watermilfoil could inhabit $>80 \%$ of the littoral zone in the lake, not including the riverine portion, which would encompass approximately 5,160 ha. Similar to the native species, Eurasian watermilfoil increased in frequency of occurrence in shallow water depths. The depth distribution for northern watermilfoil coincides with that of Eurasian watermilfoil at water depths between 3 and $4.5 \mathrm{~m}$. The presence of Eurasian watermilfoil in the native plant beds could lead to localized extirpation of some native species (Madsen et al. 1991b, 2008).

Management Assessment. 2007 Assessment. During 2007, the presence of Eurasian watermilfoil significantly increased lake-wide from the time of the pretreatment survey $(8.3 \%)$ to the posttreatment survey $(12.5 \%)$ when all management techniques were analyzed together (Madsen and Wersal 2008, data not presented). Triclopyr was the only management technique that reduced the presence of Eurasian watermilfoil in 2007. The presence of Eurasian watermilfoil in triclopyr treatment areas during the pretreatment survey was $61 \%$ and decreased to $18 \%$ during the posttreatment survey, a reduction of $70 \%(\mathrm{P}<$ 0.01; Madsen and Wersal 2008).

Eurasian watermilfoil presence did not change in fluridone treated locations between the pre- $(45 \%)$ and posttreatment (40\%) surveys (Madsen and Wersal 2008, data not presented). Fluridone often requires a long contact time with target plants, typically 60 to $90 \mathrm{~d}$ (Netherland et al. 1993), and a posttreatment survey within less than 90 $\mathrm{d}$ after treatment is not adequate to assess the effectiveness of a fluridone treatment. The assessment survey conducted in 2007 was done approximately 4 wk after herbicide applications, meaning that the majority of fluridone treatments only had 30 to $35 \mathrm{~d}$ contact time, which is 

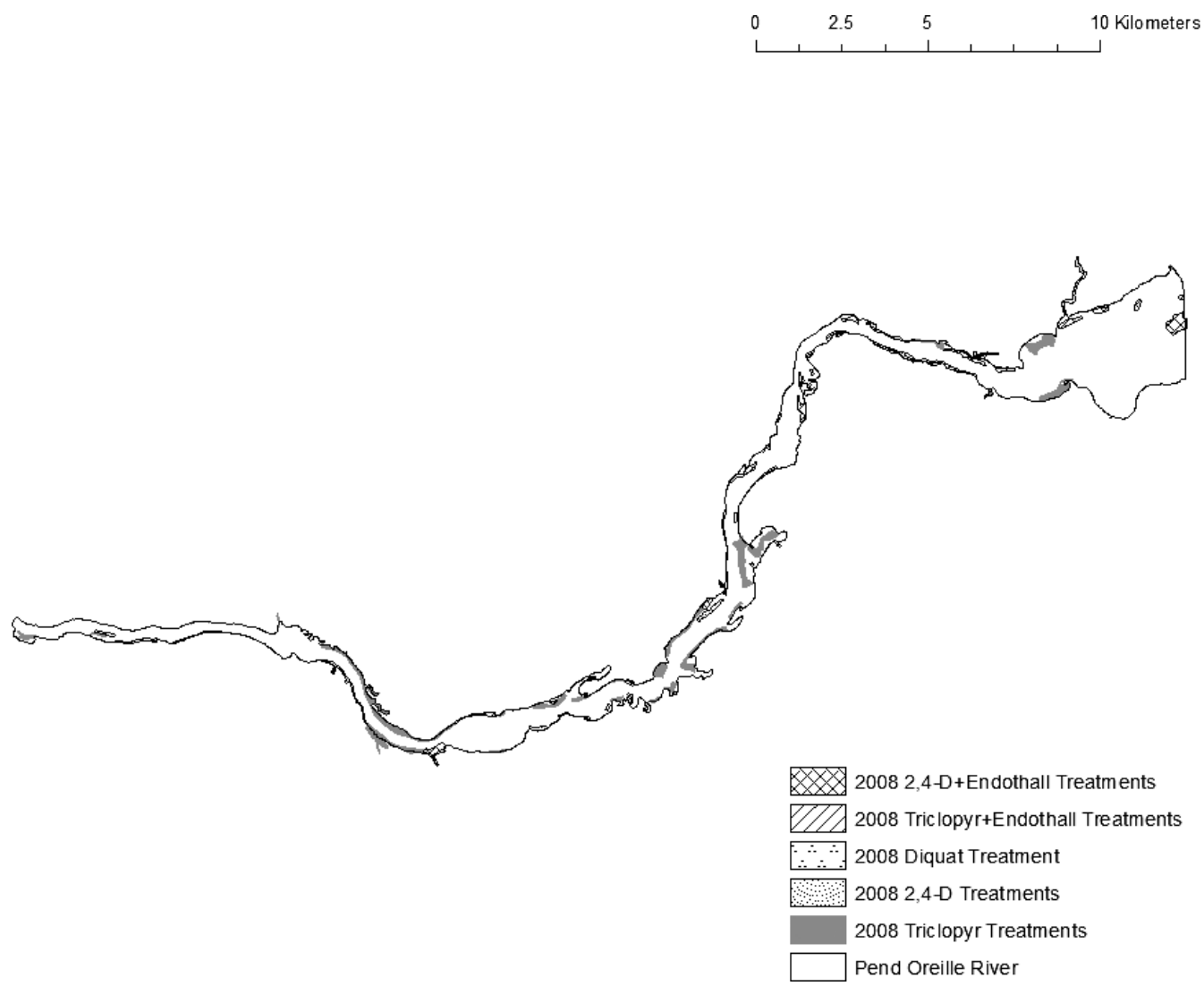

Figure 5. Treatment areas in the river portion of Lake Pend Oreille during the 2008 application season. 2,4-D was treated on 104 ha in 49 plots, triclopyr on 212 ha in 25 plots, a 2,4-D/endothall combination on 38 ha in 7 plots, and diquat on 1.6 ha in 1 plot. Triclopyr/endothall combinations were not used on any plots in the riverine portion in 2008.

too soon for an accurate assessment of fluridone efficacy. Therefore, as part of the 2008 survey, areas that were treated with fluridone in 2007 were reassessed to see if control of Eurasian watermilfoil was achieved in the year after treatment. The presence of Eurasian watermilfoil significantly decreased between 2007 and 2008 when all sites were analyzed together (Table 3 ). Eurasian watermilfoil was observed at $40 \%$ of the sample points during the 2007 assessment and $25 \%$ of the sample points during the 2008 reassessment. This difference is being driven by the effectiveness of fluridone in protected sites that are not subject to high water exchange. In these protected areas, Eurasian watermilfoil decreased from $36.6 \%$ (2007) to $2.1 \%$ (2008), a $93 \%$ reduction. The prime example of this success is the treatment in Cocolalla Creek. This site is a wide portion of the creek created by a culvert under a county road. In essence, this site is a small impoundment, with limited flows in the summer. Conversely, there was no difference in the presence of Eurasian watermilfoil between 2007 and 2008 in areas of high water exchange. Eurasian watermilfoil was observed at $41.6 \%$ and $32.8 \%$ of sampled points in 2007 and 2008, respectively. These sites are either in the riverine portion of the reservoir (Laclede), or in unprotected areas adjacent to deep water (Oden Bay, Pack
River Delta). Although managers knew that these unprotected sites were not likely areas for success with fluridone, the presence of drinking water intakes near these sites determined the selection of herbicide to at least try to control Eurasian watermilfoil.

Similar to fluridone treatments, diver dredging also was not effective at reducing Eurasian watermilfoil in 2007 (Madsen and Wersal 2008, data not presented). Eurasian watermilfoil was observed at $36 \%$ percent of sample points within diver-dredged areas during the pretreatment survey and at $46 \%$ of sample points at those same locations during the posttreatment survey. Diver dredging was effective at reducing both biomass and percent cover of Eurasian watermilfoil in Lake George, New York (Eichler et al. 1993). Diver dredging, however, was only conducted in small plots with a total area of approximately 0.28 ha in an 11,000-ha lake (Eichler et al. 1993). Furthermore, if Eurasian watermilfoil densities were high and intermingled with native species, the percent cover of native plants is adversely affected by diver dredging (Eichler et al. 1993). Although Eurasian watermilfoil can be selectively removed using diver dredging, it is best suited for small pioneering infestations. 
Table 2. Aquatic macrophyte occurrence in Lake Pend Oreille during late July to August for the 2007 and 2008 littoral zone surveys. Differences between years were determined at a $\mathrm{P} \leq 0.05$ significance level using a Cochran-Mantel-Haenszel test. Differences in species richness were determined using a Wilcoxon rank sum test at a $\mathrm{P} \leq 0.05$ significance level.

\begin{tabular}{|c|c|c|c|c|}
\hline \multirow[b]{2}{*}{ Species } & \multirow[b]{2}{*}{ Common name } & \multicolumn{2}{|c|}{$\%$ Occurrence } & \multirow[b]{2}{*}{$P$ value } \\
\hline & & 2007 & 2008 & \\
\hline Butomus umbellatus $\mathrm{L}$. & Flowering rush & 0.1 & 0.1 & 0.53 \\
\hline Callitriche sp. & Water-starwort & 0.1 & 0.1 & 0.95 \\
\hline Ceratophyllum demersum $\mathrm{L}$. & Coontail & 4.5 & 4.0 & 0.38 \\
\hline Chara sp. & Muskgrass & 29.4 & 22.0 & $<0.01$ \\
\hline Elatine minima (Nutt.) Fisch. and Mey. & Waterwort & 0.7 & 0.8 & 0.88 \\
\hline Elodea canadensis Michx. & Elodea & 8.7 & 9.0 & 0.95 \\
\hline Heteranthera dubia (Jacq.) Small & Water stargrass & 0.1 & 0.0 & 0.33 \\
\hline Hippuris vulgaris $\mathrm{L}$. & Mare’s tail & 0.1 & 0.3 & 0.43 \\
\hline Isoetes macrospora Dur. & Lake quillwort & 0.1 & 0.1 & 0.59 \\
\hline Juncus pelocarpus Mey. & Rush & 1.7 & 0.3 & 0.02 \\
\hline Lemna minor $\mathrm{L}$. & Common duckweed & 0.1 & 0.1 & 0.61 \\
\hline Myriophyllum hippuroides Torrey and Grey & Western watermilfoil & 0.1 & 0.1 & 0.14 \\
\hline Myriophyllum sibiricum Komarov & Northern watermilfoil & 2.0 & 4.2 & $<0.01$ \\
\hline Myriophyllum spicatum $\mathrm{L}$. & Eurasian watermilfoil & 12.5 & 7.9 & $<0.01$ \\
\hline Myriophyllum verticillatum $\mathrm{L}$. & Whorled watermilfoil & 1.4 & 0.0 & 0.02 \\
\hline Najas flexilis (Willd.) Rostk. and Schmidt & Slender naiad, bushy pondweed & 3.0 & 3.3 & 0.62 \\
\hline Nitella sp. & Nitella & 0.5 & 0.9 & 0.25 \\
\hline Phalaris arundinacea $\mathrm{L}$. & Reed canary grass & 0.1 & 0.4 & $<0.01$ \\
\hline Polygonum amphibium $\mathrm{L}$. & Water smartweed & 0.1 & 0.1 & 0.30 \\
\hline Potamogeton amplifolius Tuckerm. & Large-leaved pondweed & 0.1 & 0.0 & 0.16 \\
\hline Potamogeton crispus $\mathrm{L}$. & Curly-leaf pondweed & 7.8 & 9.5 & 0.08 \\
\hline Potamogeton diversifolius Raf. & Waterthread pondweed & 0.4 & 0.0 & 0.01 \\
\hline Potamogeton epihydrus Raf. & Ribbonleaf pondweed & 0.1 & 0.1 & 0.53 \\
\hline Potamogeton foliosus Raf. & Leafy pondweed & 13.7 & 14.3 & 0.69 \\
\hline Potamogeton illinoensis Morong & Illinois pondweed & 0.2 & 0.3 & 0.02 \\
\hline Potamogeton gramineus L. & Variable-leaf pondweed & 3.3 & 4.1 & 0.29 \\
\hline Potamogeton natans $\mathrm{L}$. & Floating-leaved pondweed & 0.4 & 0.2 & 0.15 \\
\hline Potamogeton nodosus Poir. & American pondweed & 0.1 & 0.2 & 0.37 \\
\hline Potamogeton praelongus Wulf. & White-stem pondweed & 0.1 & 0.6 & 0.02 \\
\hline Potamogeton pusillus L. & Narrow-leaf pondweed & 0.5 & 0.2 & 0.13 \\
\hline Potamogeton richardsonii (Ar. Benn.) Rydb. & Clasping-leaved pondweed & 6.2 & 5.1 & 0.18 \\
\hline Potamogeton robbinsii Oakes & Robbins' pondweed & 0.1 & 0.1 & 0.59 \\
\hline Potamogeton zosteriformis Fern. & Flat-stemmed pondweed & 0.8 & 1.1 & 0.48 \\
\hline Ranunculus aquatilis $\mathrm{L}$. & White water-buttercup & 3.5 & 3.9 & 0.55 \\
\hline Ranunculus reptans $\mathrm{L}$. & Creeping spearwort & 0.1 & 0.0 & 0.16 \\
\hline Sagittaria cuneata Sheldon & Arumleaf arrowhead & 0.4 & 0.1 & 0.02 \\
\hline Sagittaria graminea Michx. & Grassy arrowhead & 0.2 & 0.2 & 0.76 \\
\hline Sparganium angustifolium Michx. & Narrow-leaf burreed & 0.1 & 0.0 & 0.33 \\
\hline Stuckenia pectinata (L.) Börner & Sago pondweed & 7.0 & 7.0 & 0.79 \\
\hline Typha latifolia $\mathrm{L}$. & Common cattail & 0.1 & 0.7 & 0.01 \\
\hline Utricularia vulgaris $\mathrm{L}$. & Common bladderwort & 0.2 & 0.1 & 0.45 \\
\hline Zannichellia palustris $\mathrm{L}$. & Horned pondweed & 0.1 & 0.1 & 0.95 \\
\hline Native species richness (per point) & & $1.1 \pm 0.03$ & $1.0 \pm 0.03$ & 0.10 \\
\hline Mean species richness (per point) & & $1.0 \pm 0.03$ & $1.0 \pm 0.04$ & 0.46 \\
\hline Mean water depth (ft.) & & $21.6 \pm 0.43$ & $22.4 \pm 0.53$ & 0.42 \\
\hline
\end{tabular}

226 - Invasive Plant Science and Management 8, April-June 2015 
Table 3. Aquatic macrophyte occurrence after the 2008 posttreatment herbicide assessment (all treatment areas) survey of Lake Pend Oreille. Posttreatment surveys were conducted in late August to early September in 2007 and 2008. Comparisons were made with the 2007 posttreatment herbicide assessment survey for the same areas. Only areas treated before September 2008 are included in the analyses. Differences between years were determined at a $\mathrm{P} \leq 0.05$ significance level using a Cochran-Mantel-Haenszel test.

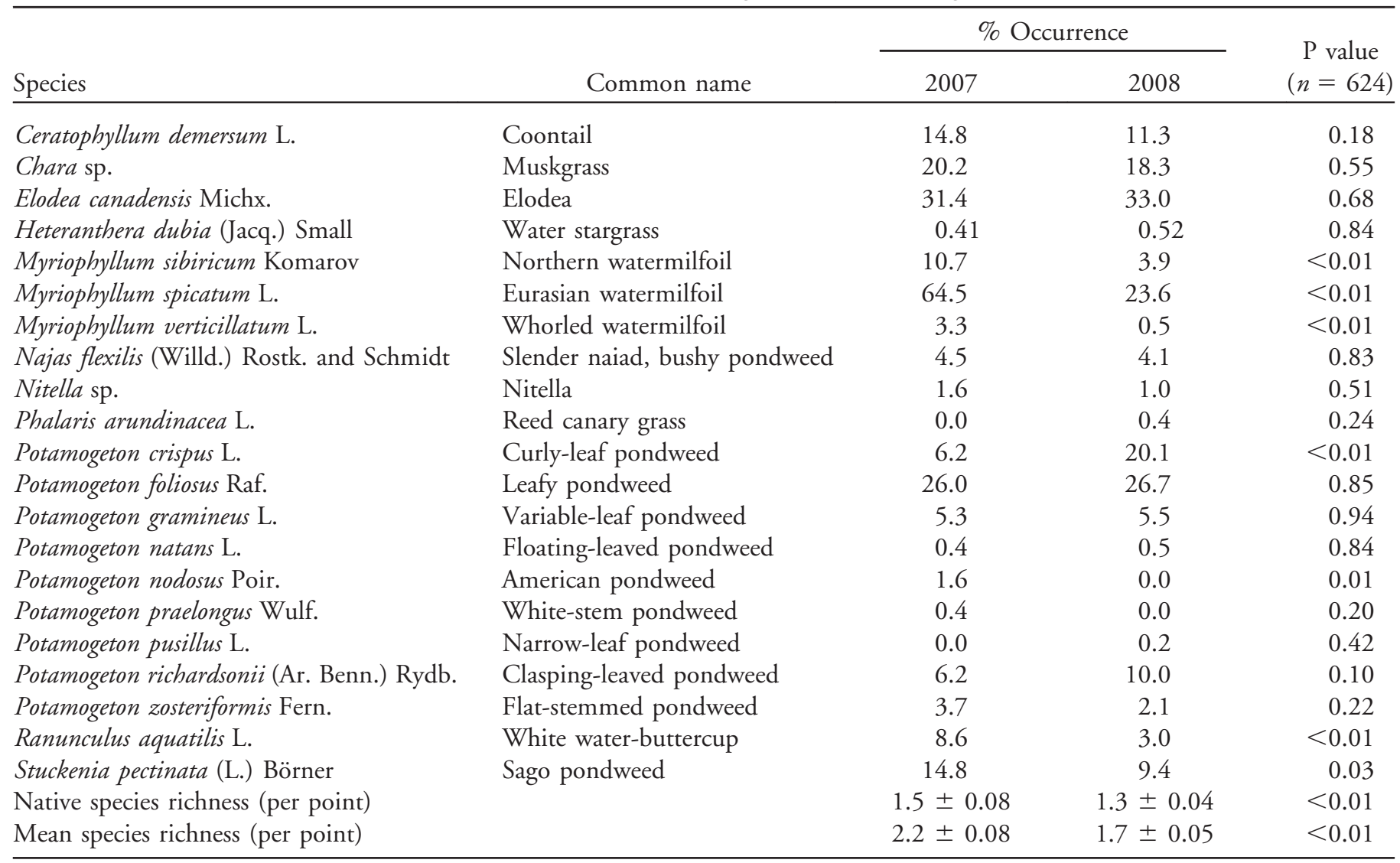

2008 Assessment. Additional treatments occurred in the fall of 2008 after the final survey was conducted. Those treatments are not included in the assessment. During 2008, only herbicides were used for Eurasian watermilfoil control given results of other techniques evaluated in 2007. Eurasian watermilfoil was selectively reduced with little effect on the native plant community. The presence of Eurasian watermilfoil during the 2008 assessment was $23.6 \%$ when all herbicides were pooled (Table 3). This represents a $63 \%$ reduction in Eurasian watermilfoil presence from the 2007 survey.

The presence of northern watermilfoil (Myriophyllum sibiricum Komarov), whorled watermilfoil (Myriophyllum verticillatum L.), and white water-buttercup (Ranunculus aquatilis L.) also decreased from 2007 to 2008 (Table 3). This is supported by differences in species richness between 2007 and 2008, during which both native species richness $(-0.2, \mathrm{P}<0.01)$ and total species richness $(-0.5, \mathrm{P}<0.01)$ declined (Table 3$)$. These species should recover from the propagule bank fairly rapidly. In a study conducted on the Pend Oreille River, WA, it was reported that the dicotyledon community was affected in the year of treatment; however, these native species increased in abundance in the absence of Eurasian watermilfoil 1 and 2 yr after treatment (Getsinger et al. 1997).

Treated/Nontreated Areas Comparison. For our treatment assessment in 2008, we compared treated sites with untreated sites ("untreated reference"), as follows. The areas that were treated before September 2008 ("treated") were compared with areas treated after September 2008 ("untreated reference," for purpose of analysis), because the treatment assessments were completed in September. The sites used as an untreated reference were not treated in 2007. Herbicide application resulted in significantly less Eurasian watermilfoil compared with untreated sites (Table 4). Eurasian watermilfoil was observed at $23 \%$ of points in areas treated before September, whereas Eurasian watermilfoil was observed at $52.5 \%$ of points not treated before September (Table 4). The removal of Eurasian watermilfoil resulted in an increase in coontail, leafy pondweed, and white water-buttercup. There were probably some site-specific impacts to white water-buttercup with respect to herbicide application; however, on the basis 
Table 4. Comparison of sites treated with any herbicide before September 2008 (Treated) and sites treated after September 2008 (Untreated). Posttreatment surveys were conducted in late August to early September of 2007 and 2008. Those areas treated after September served as an untreated reference for the purposes of analyses. Differences between treatment times were determined using a chi-square analysis. Differences in species richness were determined using a Wilcoxon rank sum test. All analyses were conducted at $\mathrm{P} \leq 0.05$ level of significance.

\begin{tabular}{llrrr}
\hline & & \multicolumn{2}{c}{$2008 \%$ Occurrence } & \\
\cline { 2 - 4 } Species & \multicolumn{1}{c}{ Common name } & Treated & Untreated & P value \\
\hline Ceratophyllum demersum L. & Coontail & 10.5 & 18.3 & 0.04 \\
Chara sp. & Muskgrass & 19.4 & 15.8 & 0.42 \\
Elatine minima (Nutt.) Fisch. and Mey. & Waterwort & 0.0 & 0.8 & 0.21 \\
Elodea canadensis Michx. & Elodea & 34.0 & 35.0 & 0.86 \\
Myriophyllum sibiricum Komarov & Northern watermilfoil & 3.1 & 6.6 & 0.14 \\
Myriophyllum spicatum L. & Eurasian watermilfoil & 23.0 & 52.5 & $<0.01$ \\
Myriophyllum verticillatum L. & Whorled watermilfoil & 0.5 & 0.8 & 0.73 \\
Najas flexilis (Willd.) Rostk. and Schmidt & Slender naiad, bushy pondweed & 4.2 & 1.6 & 0.21 \\
Nitella sp. & Nitella & 0.0 & 0.0 & 0.38 \\
Potamogeton crispus L. & Curly-leaf pondweed & 18.9 & 25.0 & 0.19 \\
Potamogeton foliosus Raf. & Leafy pondweed & 24.6 & 14.1 & 0.02 \\
Potamogeton gramineus L. & Variable-leaf pondweed & 6.8 & 6.6 & 0.96 \\
Potamogeton natans L. & Floating-leaved pondweed & 0.0 & 0.8 & 0.20 \\
Potamogeton richardsonii (Ar. Benn.) Rydb. & Clasping-leaved pondweed & 7.8 & 8.3 & 0.87 \\
Potamogeton zosteriformis Fern. & Flat-stemmed pondweed & 2.6 & 8.3 & 0.02 \\
Ranunculus aquatilis L. & White water-buttercup & 4.2 & 14.1 & $<0.01$ \\
Stuckenia pectinata (L.) Börner & Sago pondweed & 10.9 & 5.0 & 0.06 \\
Native species richness (per point) & & $1.3 \pm 0.1$ & $1.3 \pm 0.1$ & 0.65 \\
Mean species richness (per point) & & $1.7 \pm 0.1$ & $2.0 \pm 0.1$ & $<0.01$ \\
\hline
\end{tabular}

of these data, not treating Eurasian watermilfoil has a greater effect on the native plant community than herbicide treatments. The suppression and displacement of native plants by Eurasian watermilfoil has been documented in New York lakes (Madsen et al. 1991a,b). Over a 3-yr period (1987-1989) in the northwest bay of Lake George, NY, Eurasian watermilfoil spread from $30 \%$ coverage to more than $95 \%$ coverage at a monitoring site (Madsen et al. 1991b). At this same location it was reported that the native plant density was significantly reduced from 5.5 species per quadrat to 2 species (Madsen et al. 1991b). The occurrence of native species was also reduced in the presence of Eurasian watermilfoil in Waneta Lake and Lamoka Lake, NY (Madsen et al. 2008). These studies suggest that there may be a tradeoff in short-term effects of herbicides on the native plant community (Getsinger et al. 1997) or long-term reductions in native species from the growth of Eurasian watermilfoil.

Treatment Assessment. 2,4-D application did not reduce Eurasian watermilfoil presence in these assessment areas (Table 5). However, only $25 \%$ of all areas treated with 2,4$\mathrm{D}$ were evaluated, because treatments were made in mid to late September and into October after the assessment survey. The few areas that were evaluated were largely unprotected sites in the river. These areas were likely subject to increased flow and therefore adequate exposure time may have not been achieved. Curly-leaf pondweed (Potamogeton crispus L.) increased in occurrence from 2007 $(0.0 \%)$ to $2008(32.3 \%)$ in the sites evaluated. The presence of native species did not change from 2007 to 2008 in the areas evaluated with the exception of sago pondweed, which decreased in occurrence. Also, native species richness was significantly less in 2008 than 2007, which is driven by the decrease in sago pondweed. The fact that the pondweeds typically are not affected by auxinmimicking herbicides (Sprecher and Stewart 1995; Sprecher et al. 1998) indicates that other factors may have influenced the growth the aquatic macrophytes in 2008 .

Conversely, when endothall was combined with 2,4-D, Eurasian watermilfoil occurrence was reduced. Eurasian watermilfoil was observed at $63 \%$ of all points in the 2007 posttreatment survey (Table 6). In 2008, the presence of Eurasian watermilfoil was $36.5 \%$, approximately a $42 \%$ reduction in occurrence. The native plant community was not significantly affected. Furthermore, mean native species richness did not change from 2007 to 2008 at these combination treatment sites (Table 6). It has been documented in both small-scale mesocosm studies and field studies that some species selectivity may be achieved 
Table 5. Aquatic macrophyte occurrence after the 2008 posttreatment herbicide assessment of 2,4-D-treated areas in Lake Pend Oreille. Posttreatment surveys were conducted in late August to early September of 2007 and 2008. Comparisons were made with the 2007 posttreatment herbicide assessment survey for the same areas. Only areas treated before September 2008 are included in the analyses. Differences between years were determined at a $\mathrm{P} \leq 0.05$ significance level using a Cochran-Mantel-Haenszel test. Differences in species richness were determined using a Wilcoxon rank sum test at a $\mathrm{P} \leq 0.05$ significance level.

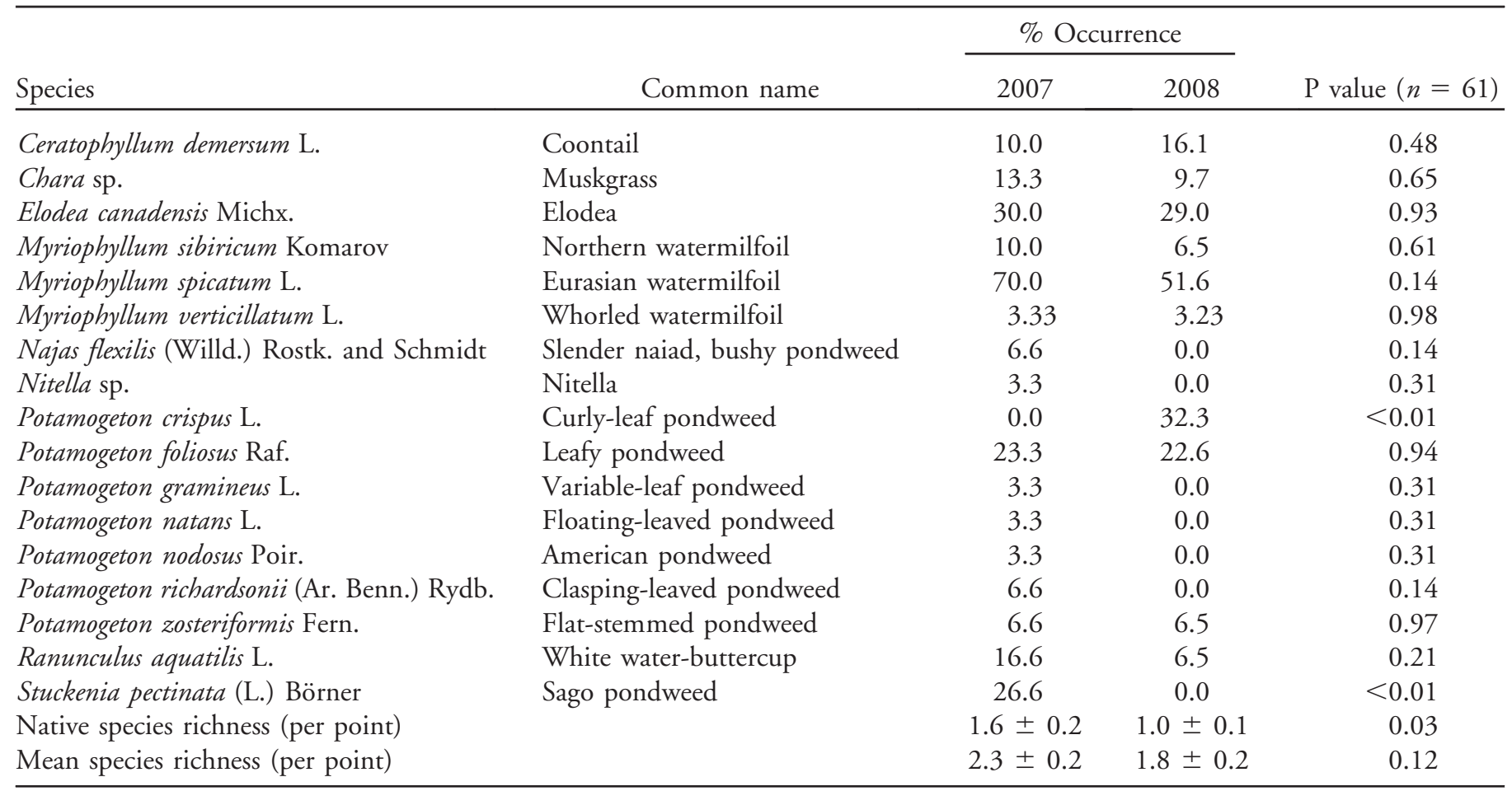

when applying endothall (Parsons et al. 2004; Skogerboe and Getsinger 2001, 2002).

The use of triclopyr resulted in a $72 \%$ reduction in the presence of Eurasian watermilfoil in the sites evaluated. In 2007, Eurasian watermilfoil frequency was $64 \%$ in the assessment survey (Table 7). Eurasian watermilfoil was reduced to $18.2 \%$ in 2008. Mean species richness decreased from 2007 and 2008 because of the removal of Eurasian watermilfoil. The native plant community, with the exception of white water-buttercup, was unaffected by triclopyr because the presence of native species did not change between years and mean native species richness was similar between years. Similar to 2,4-D-treated areas, curly-leaf pondweed increased in occurrence from 4.9 to $19 \%$ between 2007 and 2008, respectively. Triclopyr has selectively controlled Eurasian watermilfoil in Lake Pend Oreille. We are not explicitly comparing one active ingredient to another, because the treatment plots were of different sizes and had different water exchange characteristics.

A limited number of sites were available for evaluation of endothall and triclopyr combinations; therefore, we offer only percentages with no statistical analyses. The presence of Eurasian watermilfoil decreased from $67 \%$ in 2007 to $0 \%$ in 2008 (data not presented). Similar to 2,4-D, the combination of triclopyr and endothall shows promise in controlling Eurasian watermilfoil under flowing water conditions, although additional studies are needed to confirm this.

The extensive use of auxin herbicides has reduced Eurasian watermilfoil frequency, but it has released curly-leaf pondweed as shown by its increase from $6.2 \%$ in 2007 to $20.1 \%$ in 2008 (Table 3). The increasing presence of curlyleaf pondweed will undoubtedly pose different management problems because this species can root from fragments and also produces turions for survival of adverse conditions, dispersal, and plant growth. Fewer herbicides are available for curly-leaf pondweed control and none that will offer selective removal of the plant. Further research should examine varying rates and different formulations, plot size, dissipation rate, and movement of the herbicide into sediment porewater. Reporting on both apparent successes and failures will build our knowledge base to improve future management of Eurasian watermilfoil and other invasive aquatic macrophytes.

During the lake-wide management of Eurasian watermilfoil from 2007 to 2008, the presence of Eurasian watermilfoil declined while the native plant community has remained stable. Native species richness did not change from 2007 to 2008, nor did total species richness, which indicates other species are recolonizing areas when Eurasian 
Table 6. Aquatic macrophyte occurrence after the 2008 posttreatment herbicide assessment of 2,4-D and endothall combination areas in Lake Pend Oreille. Posttreatment surveys were conducted in late August to early September of 2007 and 2008. Comparisons were made with the 2007 posttreatment herbicide assessment survey for the same areas. Only areas treated before September 2008 are included in the analyses. Differences between years were determined at a $\mathrm{P} \leq 0.05$ significance level using a Cochran-Mantel-Haenszel test. Differences in species richness were determined using a Wilcoxon rank sum test at a $\mathrm{P} \leq 0.05$ significance level.

\begin{tabular}{llrrr}
\hline & & \multicolumn{2}{c}{$\%$ Occurrence } & \\
\cline { 3 - 4 } Species & \multicolumn{1}{c}{ Common name } & 2007 & 2008 & P value $(n=125)$ \\
\hline Ceratophyllum demersum L. & Coontail & 22.5 & 9.5 & 0.05 \\
Chara sp. & Muskgrass & 17.7 & 22.2 & 0.53 \\
Elodea canadensis Michx. & Elodea & 40.3 & 47.6 & 0.41 \\
Heteranthera dubia (Jacq.) Small & Water stargrass & 1.6 & 0.0 & 0.31 \\
Myriophyllum sibiricum Komarov & Northern watermilfoil & 4.8 & 4.8 & 0.98 \\
Myriophyllum spicatum L. & Eurasian watermilfoil & 63.0 & 36.5 & $<0.01$ \\
Myriophyllum verticillatum L. & Whorled watermilfoil & 6.4 & 0.0 & 0.04 \\
Najas flexilis (Willd.) Rostk. and Schmidt & Slender naiad, bushy pondweed & 6.4 & 6.4 & 0.98 \\
Nitella sp. & Nitella & 0.0 & 1.5 & 0.32 \\
Potamogeton crispus L. & Curly-leaf pondweed & 11.3 & 22.2 & 0.10 \\
Potamogeton foliosus Raf. & Leafy pondweed & 17.7 & 3.1 & $<0.01$ \\
Potamogeton gramineus L. & Variable-leaf pondweed & 8.1 & 6.4 & 0.71 \\
Potamogeton nodosus Poir. & American pondweed & 3.2 & 0.0 & 0.15 \\
Potamogeton praelongus Wulf. & White-stem pondweed & 1.6 & 0.0 & 0.31 \\
Potamogeton richardsonii (Ar. Benn.) Rydb. & Clasping-leaved pondweed & 1.6 & 6.4 & 0.17 \\
Potamogeton zosteriformis Fern. & Flat-stemmed pondweed & 4.8 & 1.6 & 0.30 \\
Ranunculus aquatilis L. & White water-buttercup & 4.8 & 3.2 & 0.63 \\
Stuckenia pectinata (L.) Börner & Sago pondweed & 6.4 & 3.2 & 0.39 \\
Native species richness (per point) & & $1.4 \pm 0.1$ & $1.2 \pm 0.1$ & 0.10 \\
Mean species richness (per point) & & $2.1 \pm 0.2$ & $1.7 \pm 0.1$ & 0.03 \\
\hline
\end{tabular}

watermilfoil has been removed. Continued surveying and monitoring will be crucial in sustaining a successful management program, especially on a lake of this size, and determining the differences in Eurasian watermilfoil population dynamics between oligotrophic lakes and historic infestations of many eutrophic lakes in Midwestern states. The suitable habitats in oligotrophic lakes are usually much smaller and more isolated than those in eutrophic lakes, and nonnative plants such as Eurasian watermilfoil tend to form isolated beds because of the patchiness of suitable littoral zone habitat (Madsen 1994). Once an oligotrophic lake is colonized by nonnative species, growth is slower, likely because of lower temperatures, shorter growing seasons, and reduced nutrient availability (Madsen 1994). Therefore, Eurasian watermilfoil is likely to invade areas in oligotrophic lakes that have native species already present, because these areas provide an optimal environment for growth. Eurasian watermilfoil can invade speciesrich native plant communities; areas of high native species richness have a greater probability of being invaded (Capers et al. 2007).

Although native species richness does not completely prevent invasion, it may be important to promote and maintain native plant density, because this has been shown to resist invasion (Capers et al. 2007). Dense native plant beds are presumably better able to prevent the colonization and establishment by intercepting nonnative propagules, reducing the success of invasion (Capers et al. 2007). Additionally, Chadwell and Engelhardt (2008) concluded that reducing propagule pressure (i.e., the dispersal mechanism of the target plant, whether seeds, fragments, tubers, or turions) through targeted management is necessary to slow the spread of the target species. Also, the restoration of a dense native plant community may be a further defense against future invasion, as well as providing other ecosystem services. Therefore, a combined strategy of targeted control and promotion of native plant growth may be the most sustainable and cost-effective strategy for managing Eurasian watermilfoil in Lake Pend Oreille. The fact that the presence of Eurasian watermilfoil has declined and the native community has remained stable is evidence that Eurasian watermilfoil can be selectively targeted, leaving the native community to possibly resist further invasions.

By 2012, approximately 200 ha of Eurasian watermilfoil remained in Lake Pend Oreille; the management 
Table 7. Aquatic macrophyte occurrence after the 2008 posttreatment herbicide assessment of triclopyr-treated areas in Lake Pend Oreille. Posttreatment surveys were conducted in late August to early September of 2007 and 2008. Comparisons were made with the 2007 posttreatment herbicide assessment survey for the same areas. Only areas treated before September 2008 are included in the analyses. Differences between years were determined at a $\mathrm{P} \leq 0.05$ significance level using a Cochran-Mantel-Haenszel test. Differences in species richness were determined using a Wilcoxon rank sum test at a $\mathrm{P} \leq 0.05$ significance level.

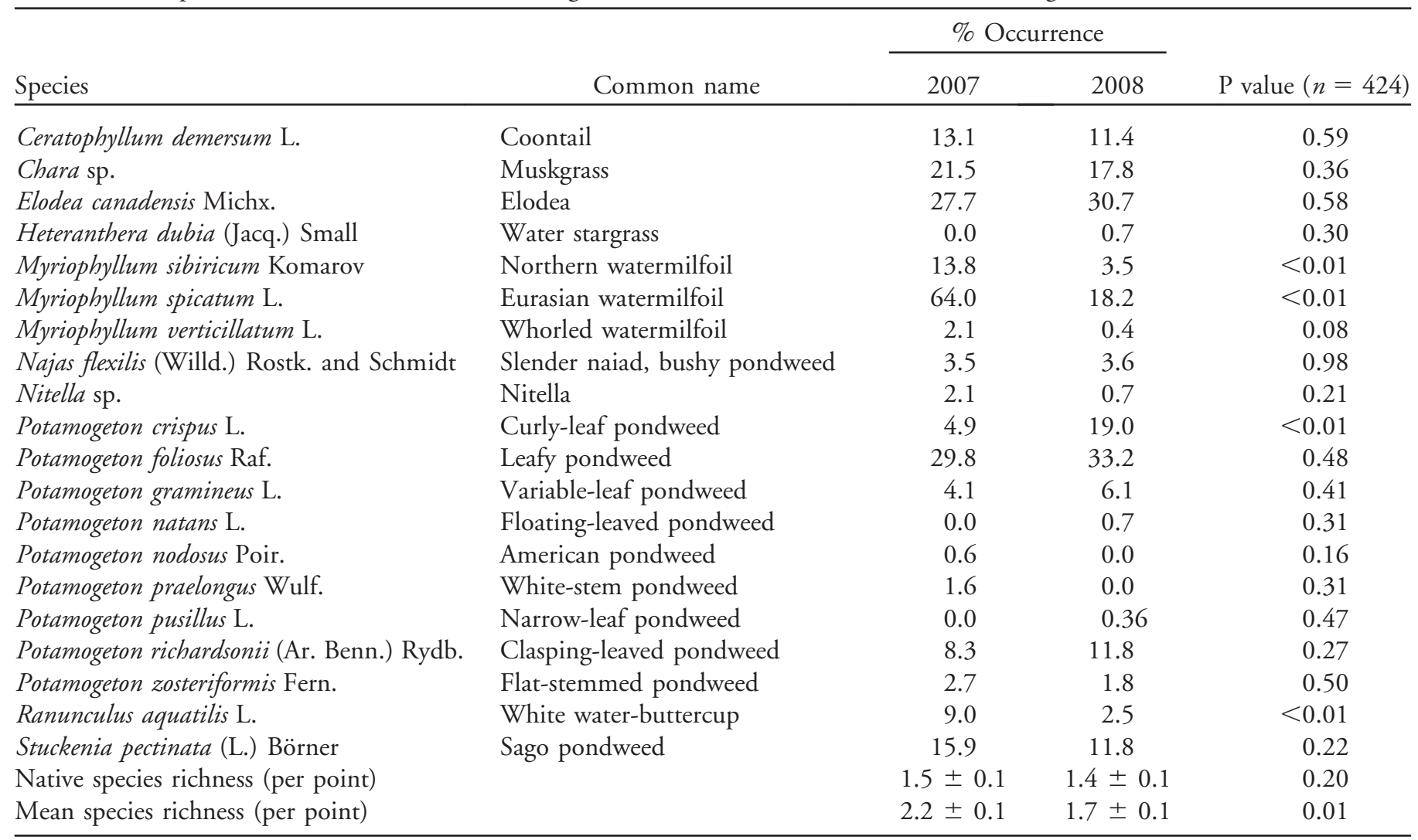

program conducted over the last 7 to $8 \mathrm{yr}$ has been effective at reducing the frequency of Eurasian watermilfoil by $90 \%$. Although we believe that quantitative evaluations to assess management programs are indispensable, we recognize that it is difficult, at best, to apply a single monitoring technique and timing to different herbicides applied at different times. Data interpretation should consider not only the time of treatment, but the response time of the target plant to each individual herbicide applied, because the full plant response might not be seen until the following season. Consistent evaluation, properly and conservatively interpreted, will provide a guide for which treatments are effective and which are not, and in evaluating whether management program goals are met.

\section{Acknowledgments}

Funding was provided by the Idaho State Department of Agriculture through a contract with the Aquatic Ecosystem Restoration Foundation, Mr. Carlton Layne, Executive Director. We thank Brad Bluemer, who provided historical information regarding Lake Pend Oreille and also provided additional logistic support during our surveys, which was invaluable. We also thank Dr. Wilfredo Robles, Joshua Cheshier, Jimmy Peeples, and Waldemar Robles. Dr. Bill Haller, Dr. Kurt Getsinger, and Dr. Wilfredo Robles provided reviews of an earlier version of this manuscript. Mention of a manufacturer does not constitute a warranty or guarantee of the product by the U.S. Department of Agriculture or an endorsement over other products not mentioned.

\section{Literature Cited}

Barko JW, Adams MS, Clesceri NS (1986) Environmental factors and their consideration in the management of submersed aquatic vegetation: a review. J Aquat Plant Manage 24:1-10

Capers RS, Selsky RS, Bugbee GJ, White JC (2007) Aquatic plant community invasibility and scale-dependent patterns in native and invasive species richness. Ecology 88:3135-3143

Carpenter SR, Lodge DM (1986) Effects of submersed macrophytes on ecosystem processes. Aquat Bot 26:341-370

Case ML, Madsen JD (2004) Factors limiting the growth of Stuckenia pectinata (sago pondweed) in Heron Lake, Minnesota. J Freshw Ecol 19:17-23 
Chadwell TB, Engelhardt KAM (2008) Effects of pre-existing submersed vegetation and propagule pressure on the invasion success of Hydrilla verticillata. J Appl Ecol 45:515-523

Crowell WJ, Proulx NA, Welling CH (2006) Effects of repeated fluridone treatments over nine years to control Eurasian watermilfoil in a mesotrophic lake. J Aquat Plant Manage 44: $133-136$

Doyle RD (2000) Effects of Navigation on Aquatic Plants: Effects of Sediment Resuspension and Deposition on Plant Growth and Reproduction. Vicksburg, MS: U.S. Army Corps of Engineers Upper Mississippi River-Illinois Waterway System Navigation Study, ENV Rep. 28. $64 \mathrm{p}$

Eichler LW, Bombard RT, Sutherland JW, Boylen CW (1993) Suction harvesting of Eurasian watermilfoil and its effect on native plant communities. J Aquat Plant Manage 31:144-148

Engelhardt KAM, Ritchie ME (2002) The effect of aquatic plant species richness on wetland ecosystem processes. Ecology 83:2911-2924

Getsinger KD, Turner EG, Madsen JD, Netherland MD (1997) Restoring native vegetation in a Eurasian watermilfoil dominated plant community using the herbicide triclopyr. Regul Rivers Res Manage 13:357-375

Hofstra DE, Clayton JS (2001) Evaluation of selected herbicides for the control of exotic submersed weeds in New Zealand: I. The use of endothall, triclopyr and dichlobenil. J Aquat Plant Manage 39:20-24

Keast A (1984) The introduced macrophyte, Myriophyllum spicatum, as a habitat for fish and their invertebrate prey. Can J Zool 62: $1289-1303$

Krull JN (1970) Aquatic plant-invertebrate associations and waterfowl. J Wildl Manage 34:707-718

Lillie RA, Budd J (1992) Habitat architecture of Myriophyllum spicatum as an index to habitat quality for fish and macroinvertebrates. J Freshw Ecol 7:113-125

Madsen JD (1994) Invasions and declines of submersed macrophytes in Lake George and other Adirondack lakes. Lake Reservoir Manage 10: $19-23$

Madsen JD (1998) Predicting invasion success of Eurasian watermilfoil. J Aquat Plant Manage 36:28-32

Madsen JD (1999) Point and Line Intercept Methods for Aquatic Plant Management. Vicksburg, MS: U.S. Army Engineer Research and Development Center, Aquatic Plant Control. Research Program Technical Notes Collection TN APCRP-M1-02, $16 \mathrm{p}$

Madsen JD, Bloomfield JA, Sutherland JW, Eichler LW, Boylen CW (1996) The aquatic macrophyte community of Onondaga Lake: field survey and plant growth bioassays of lake sediments. Lake Reservoir Manage 12:73-79

Madsen JD, Chambers PA, James WF, Koch EW, Westlake DF (2001) The interactions between water movement, sediment dynamics and submersed macrophytes. Hydrobiologia 444:71-84

Madsen JD, Hartleb CF, Boylen CW (1991a) Photosynthetic characteristics of Myriophyllum spicatum and six submersed macrophyte species native to Lake George, New York. Freshwater Biol 26: 233-240

Madsen JD, Stewart RM, Getsinger KD, Johnson RL, Wersal RM (2008) Aquatic plant communities in Waneta Lake and Lamoka Lake, New York. Northeast Nat 15:97-110

Madsen JD, Sutherland JW, Bloomfield JA, Eichler LW, Boylen CW (1991b) The decline of native vegetation under dense Eurasian watermilfoil canopies. J Aquat Plant Manage 29:94-99
Madsen JD, Wersal RM (2008) Assessment of Eurasian Watermilfoil (Myriophyllum spicatum L.) Populations in Lake Pend Oreille, ID for 2007. Final report submitted to the Idaho State Department of Agriculture in April 2008. GeoResources Institute Report 5028

Madsen JD, Wersal RM (2009) Aquatic Plant Community and Eurasian watermilfoil (Myriophyllum spicatum L.) Management Assessment in Lake Pend Oreille, Idaho for 2008. Final report submitted to the Idaho State Department of Agriculture in March 2009. Mississippi State, MS: Geosystems Research Institute Report 5032. $116 \mathrm{p}$

Netherland MD, Getsinger KD, Turner EG (1993) Fluridone concentrations and exposure time requirements for control of Eurasian watermilfoil and hydrilla. J Aquat Plant Manage 31: 189-194

Ozimek T, Gulati RD, van Donk E (1990) Can macrophytes be useful in biomanipulation of lakes? The Lake Zwemlust example. Hydrobiologia 200/201:399-407

Parsons JK, Hamel KS, O'Neal SL, Moore AW (1994) The impact of endothall on the aquatic plant community of Kress Lake, Washington. J Aquat Plant Manage 42:109-114

Savino JF, Stein RA (1989) Behavior of fish predators and their prey: habitat choice between open water and dense vegetation. Environ Biol Fishes 24:287-293

Shea K, Chesson P (2002) Community ecology theory as a framework for biological invasions. Trends Ecol Evol 17:170-176

Simberloff D (2003) Eradication-preventing the invasion at the outset. Weed Sci 51:247-253

Skogerboe JG, Getsinger KD (2001) Endothall species selectivity evaluation: southern latitude aquatic plant community. J Aquat Plant Manage 39:129-135

Skogerboe JG, Getsinger KD (2002) Endothall species selectivity evaluation: northern altitude aquatic plant community. J Aquat Plant Manage 40:1-5

Sprecher SL, Getsinger KD, Stewart AB (1998) Selective effects of aquatic herbicides on sago pondweed. J Aquat Plant Manage 36:64-68

Sprecher SL, Stewart AB (1995) Triclopyr effects on peroxidase activity in target and non-target aquatic plants. J Aquat Plant Manage 33:43-48

Stokes ME, Davis CS, Koch GG (2000) Categorical Data Analysis Using the SAS ${ }^{\circledR}$ System. 2nd edn. Cary, NC: SAS Institute. $648 \mathrm{p}$

[USEPA] U.S. Environmental Protection Agency (1993) Clark ForkPend Oreille Basin Water Quality Study: Summary of Findings and a Management Plan. Helena, MT: U.S. Environmental Protection Agency, Region 8, January 1993. $126 \mathrm{p}$

Wersal RM, Madsen JD, McMillan BR, Gerard PD (2006) Environmental factors affecting biomass and distribution of Stuckenia pectinata in the Heron Lake System, Minnesota, USA. Wetlands 26: 313-321

Wersal RM, Madsen JD, Woolf TE, Eckberg N (2010) Assessment of herbicide efficacy on Eurasian watermilfoil and impacts to the native submersed plant community in Hayden Lake, Idaho, USA. J Aquat Plant Manage 48:5-11

Wetzel RG (2001) Limnology: Lake and River Ecosystems. 3rd edn. San Diego: Academic Press. 1006 p

Received January 28, 2014, and approved February 11, 2015. 